\title{
OPTIMALISASI POTENSI SUMBER DAYA PETANI UNTUK PEMELIHARAAN SAPI POTONG RAKYAT PADA BASIS PERTANIAN BERBEDA DI SUMATERA BARAT
}

\author{
Asdi Agustar, James Hellyward dan Mardiati Zein \\ Fakultas Peternakan, Universitas Andalas
}

\begin{abstract}
Beef cattle raising have been doing as sideline business in farming systems. Such conditions lead to frequent farmers are not fully paying attention. Therefore, the potential for increased economic value is very likely obtained when competencies resource owned by the farmers can be utilized optimally. The study aims to map the the resource owned by the farmers in particular the potential of land, feed resouces and family labour. The study was conducted at three (3) areas with different agricultural commodity basis, using the survey with 180 respondent randomly selected. The results shown that farmers at the smallholders estate area have more resources than both farners in the crop and horticulture basis areas. In all three areas of research, utilization of resoources are still not optimal. Optimizing the use of available resources is still possible to increase the scale of beef cattle raising in the three areas of research.
\end{abstract}

\section{PENDAHULUAN}

Konsumsi daging sapi yang terus mengalami peningkatan di Indonesia, belum diimbangi dengan peningkatan produksi yang memadai. Oleh sebab itu impor daging sapi dan sapi bakalan merupakan alternatif yang belum bisa dihindari. Selama periode 1990-1998 volume impor daging sapi mengalami peningkatan setiap tahun rata-rata 38,55 persen (FAO dalam Ilham et al., 2001). Impor daging sapi dan sapi bakalan tidak hanya menguras devisa negara, tetapi juga menyebabkan hilangnya kesempatan tenaga kerja sehingga tingkat produktifitas petani tetap rendah (Agustar, 2008).

Di Indonesia pemeliharaan sapi potong masih didominasi oleh peternakan rakyat yang terintegrasi dengan usahatani lainnya. Memelihara sapi potong hanya dilakukan sebagai usaha sambilan di samping bertani. Pada tingkatan yang lebih tinggi dari itu, peternakan dijadikan sebagai cabang usaha (farm entreprises) (Mosher, 1966; Davendra, 1993). Kondisi yang demikian menyebabkan seringnya petani tidak memberikan perhatian serta alokasi sumberdaya yang dimiliki secara optimal dalam memelihara sapi potong. Kondisi tersebut menyebabkan produktivitas peternak dan produksi ternak yang dipeliharanya masih lebih rendah dari potensi yang dimilikinya. Peneltian ini bertujuan untuk memetakan potensi petani/peternak untuk mendukung pemeliharaan sapi potong yang efektif, efisien pada berbagai basis pertanian di Sumatera Barat.

\section{Kerangka Pemikiran}

Terwujudnya masyarakat yang sehat, produktif, dan kreatif melalui pembangunan peternakan tangguh berbasis sumberdaya lokal merupakan visi pembangunan peternakan. Penggunaan sumberdaya lokal akan berimplikasi keberpihakan kepada rakyat (kerakyatan), kesinambungan, dan desentralisasi.
Dengan eksistensi ketiga substansi tersebut diharapkan mampu terciptanya peternakan yang tangguh. Pada gilirannya peternakan yang tangguh karena ditopang sumberdaya lokal diharapkan menjadi modal dasar untuk mewujudkan swasembada komoditi peternakan dan mampu meningkatkan kesejahteraan peternak rakyat.

Dari kajian makro, Sumatera Barat memiliki potensi yang baik untuk pengembangan sapi potong karena didukung oleh budaya masyarakat, kebijakan pemerintah, dan potensi sumberdaya alam (Agustar et al., 2004). Kondisi ini pula yang dijadikan pertimbangan sehingga Provinsi Sumatera Barat ditetapkan sebagai salah satu daerah sentra produksi sapi potong.

Potensi produksi dan reproduksi ternak sapi potong lokal yang dipelihara di wilayah Sumatera Barat cukup baik namun belum mampu ditampilkan secara optimal (Lab. Reproduksi Faterna Unand, 2006). Pemeliharaan sapi potong masih dilakukan dengan pola tradisional, alokasi penggunaan sumberdaya yang ada belum efektif dan efisien sehingga tingkat pendapatan peternak belum optimal (Agustar dan Jaswandi, 2006). Peternak lebih tertarik untuk memelihara sapi exotic dengan bobot yang besar walaupun ia harus mengeluarkan biaya lebih besar karena berbagai input produksi harus didatangkan dari luar sistem usaha tani yang ia lakoni. Kebiasaan yang demikian sebetulnya tidak meningkatkan produktivitas tenaga kerja dan membangun ketergantungan kepada pihak luar yang akhirnya tingkat keberlanjutan usahanya rendah (Agustar, 2010).

Kedepan, pola penggunaan sumberdaya lokal dalam pemeliharaan ternak potong perlu dilakukan perubahan. Integrasi sapi potong lokal dengan pertanian tanaman pangan, perkebunan ataupun hortikultura perlu dilakukan kajian karena Sumatera Barat memiliki wilayah dengan basis 3 komoditi tersebut. Untuk itu perlu diketahui potensi optimal 
faktor produksi pada tingkat rumah tangga peternak yang mempengaruhi pengembangan usaha peternakan sapi potong. Selanjutnya juga perlu dilakukan kajian untuk mengetahui kesesuaian potensi yang dimiliki dengan jenis ternak lokal yang ada di Sumatera Barat untuk menampilkan kinerja sapi lokal yanng optimal dan tingkat pendapatan yang paling baik. Berdasarkan rangkaian kajian tersebut diharapkan didapatkan pola dan model pemeliharaan sapi potong berbasis penggunaan potensi lokal yang optimal.

\section{MATERI DAN METODE}

Penelitian dilakukan dengan metode survei pada 3 (tiga) wilayah dengan basis pertanian yang berbeda yaitu: 1) wilayah dengan basis tanaman pangan; 2) wilayah dengan basis perkebunan; dan 3) wilayah dengan basis hortikultura. Pemilihan lokasi penelitian dilakukan secara purposive, dengan kriteria yang dijadikan dasar untuk memilih: 1) luas area dan jumlah petani yang mengusahakan jenis komoditi pertanian sebagai basis.; 2) dukungan kebijakan pemerintah daerah untuk mengembangkan komoditi pertanian yang menjadi basis; 3) kemudahan keterjangkauan lokasi berdasar infrastuktur transportasi. Yang dijadikan sampel pada penelitian ini adalah rumah tangga petani yang terdaftar sebagai penduduk tetap pada lokasi penelitian. Penentuan jumlah sampel dilakukan dengan kuota (Quota sampling). Setiap lokasi penelitian ditetapkan sampel sebanyak 60 rumah tangga petani, sehingga didapatkan sebanyak 180 Rumah Tangga sampel. Pengambilan sampel dilakukan dengan teknik acak sederhana (simple random sampling).

Yang dijadikan responden pada setiap rumah tangga yang terpilih sebagai sampel adalah Kepala Rumah Tangga (suami). Apabila tidak memungkinkan karena satu dan lain hal, maka responden diganti dengan istri atau salah seorang anggota keluarga yang dapat memberikan data atau informasi berkenaan dengan data atau informasi yang dikumpulkan pada penelitian ini.

Data primer yang dikumpulkan bertujuan untuk mendiskripsikan sumberdaya yang dikuasai rumah tangga untuk pemeliharaan sapi potong. Adapun sumberdaya yang dimaksudkan meliputi:

a. Potensi Lahan yang dimiliki/dikuasai petani

b. Potensi Tenaga Kerja Keluarga

c. Potensi Sumber pakan ternak yang dikuasai atau yang mampu diakses

Untuk menunjang data primer, juga dikumpulkan data sekunder terutama yang berkenaan dengan: kondisi alam wilayah dan kebijakan dan program pemerintah daerah terutama pada sektor pertanian umumnya dan komoditi pertanian khususnya. Pengumpulan data primer dilakukan melalui wawancara berdasarkan daftar pertanyaan (kuesioner) terstruktur. Selain itu juga dilakukan observasi pada setiap lokasi penelitian.

Pengolahan data dilakukan dengan menggunakan package program SPSS, dan analisa data menggunakan statistik diskriptif, yang meliputi: rata-rata, persentase, dan standar deviasi (SD).

\section{Definisi Operasional dan Pengukuran}

1) Potensi lahan adalah jumlah luasan lahan yang dimiliki atau dikuasai (dapat dimanfaatkan) petani, untuk melakukan pertanian dan memelihara ternak. Pengukuran luas lahan dihitung dalam Hekto Are (HA).

2) Potensi Pakan adalah prediksi produksi hijauan alam maupun yang bisa ditanam pada lahan yang dimiliki atau dikuasai petani dan prediksi hasil limbah pertanian yang dilakukan petani pada lahan tersebut. Pengukuran potensi pakan dilakukan dalam satuan Ton Bahan Kering (BK) per Tahun.

3) Potensi Tenaga Kerja Keluarga adalah Ketersediaan Tenaga Kerja keluarga dikurangi dengan Curahan Tenaga kerja untuk kegiatan Pekerjaan Utama (produktif) dan kegiatan Reproduktif. Pengukuran dilakukan dalam Hari Kerja Setara Pria (HKP), dimana untuk laki-laki dewasa $=1 \mathrm{HKP}$ dan Perempuan Dewasa $=0,8$ HKP bekerja 8 jam per hari.

\section{HASIL DAN PEMBAHASAN}

\section{Potensi Lahan dan Daya Dukung Pakan}

Lahan merupakan faktor produksi utama dalam sistim usaha tani baik pada usaha tani berbasis tanaman pangan, perkebunan maupun usaha tani yang berbasis hortikultura. Keberadaan lahan juga dijadikan dasar dalam penetapan pola pemeliharaan sapi potong rakyat di Indonesia. Sebagaimana yang dikemukakan oleh Hermanto (2007), pada wilayah jarang penduduk pada umumnya sapi diusahakan menurut pola pemeliharaan berbasis lahan (landbase), dimana jumlah sapi yang dipelihara sangat tergantung kepada luas lahan yang dapat diakses peternak terutama sebagai tempat tumbuhnya hijauan untuk pakan ternak yang digembalakan atau dilepaskan. Sedangkan pada wilayah-wilayah padat penduduk, pemeliharaan sapi potong dilakukan dengan pola.

Provinsi Sumatera Barat mempunyai lahan seluas \pm 4.299.730 ha. Realita topografi daratan Provinsi Sumatera Barat memiliki kontur yang cenderung bergelombang, dimana luasan wilayah daratan yang didominasi wilayah perbukitan dan pegunungan yakni mencapai luas \pm 2.203 .808 ha atau $52,19 \%$ dari luas Sumatera Barat. Wilayah daratan dengan bentuk permukaan yang didominasi area yang relatif datar hanya mencapai $13,31 \%$ atau 561.888 ha. Umumnya daerah tersebut terletak pada ketinggian 0-50 meter di atas permukaan laut.

\section{Lahan dan Daya Dukung Pakan Pada Wilayah Perkebunan}

Lahan kelapa sawit merupakan potensi untuk pemeliharaan sapi potong melalui sistem pemeliharaan integrasi sapi dengan kelapa sawit yang akhir- 
akhir ini populer dengan sebutan SISKA. Lahan kelapa sawit merupakan sumber hijauan yang dapat dimanfaatkan sapi. Diperkirakan sekitar 70-80\% dari areal perkebunan kelapa sawit dapat dimanfaatkan sebagai sumber hijauan pakan ternak (Chen dan Dahlan, 1995). Selain itu, limbah kebun kelapa sawit terutama daun dan pelepahnya merupakan potensi bahan pakan untuk sapi potong yang selama ini belum dimanfaatkan secara optimal.

Setelah kelapa sawit, coklat/kakao merupakan komoditi perkebunan kedua terluas di Sumatera Barat. Limbah coklat terutama kulit buahnya juga merupakan potensi pakan ternak ruminansia yang belum dimanfaatkan sebagai sumber pakan. Data Dinas Perkebunan Provinsi Sumatera Barat menyatakan pada tahun 2009 terdapat 77.482 ha kebun coklat dengan produksi dengan produksi biji coklat sebanyak 32.889 ton/tahun. Coklat pada umumnya diusahakan oleh petani rakyat dengan rata-rata luas lahan lebih kecil dibandingkan dengan penguasaan kebun kelapa sawit petani rakyat. Selain itu, coklat juga banyak ditanam sebagai tanaman campuran dengan berbagai komoditi perkebunan lainnya pada lahan pekarangan atau lahanlahan disekitar rumah tempat tinggal. Oleh sebab itu, tidak semua lahan kebun coklat rakyat memupunyai potensi sebagai penghasil hijauan sebagaimana halnya pada lahan kebun kelapa sawit. Namun demikian, limbah kulit buah coklat merupakan potensi pakan ternak yang masih belum dimanfaatkan secara optimal oleh petani rakyat.

Lahan kebun sawit yang dimiliki petani dapat dikategorikan atas lahan sawit yang sudah berproduksi dan lahan sawit yang belum berproduksi. Pada lokasi pengambilan sampel penelitian, petani memiliki lahan kelapa sawit berkisar antara 0,5 ha yang terendah dan 26 ha yang tertinggi, dengan rata-rata 5,03 ha/ petani. Keragaan pemilikan lahan kebun sawit dapat dilihat pada Tabel 1 .

Tabel 1. Pemilikan Lahan Kebun Sawit Responden

\begin{tabular}{cccc}
\hline No. & $\begin{array}{c}\text { Rentangan Pengua- } \\
\text { saan Lahan Petani } \\
(\mathrm{Ha})\end{array}$ & Jumlah & Persentase \\
\hline 1. & $<2$ & 11 & 26,2 \\
2. & $2-4$ & 15 & 35,7 \\
3. & $+4-6$ & 6 & 14,3 \\
4. & $+6-8$ & 4 & 9,5 \\
5. & +8 & 6 & 14,3 \\
\hline Total & & 42 & 100,0 \\
\hline
\end{tabular}

Pada lahan yang sudah berproduksi, maka pemeliharaan sapi potong didalam kebun tidak akan menimbulkan kerusakan terhadap tanaman. Dengan demikian pemeliharaan sapi potong dan jumlah sapi per satuan luas lahan dapat dilakukan secara optimal. Sedangkan pada lahan sawit yang belum berproduksi, pemeliharaan sapi potong pada lahan yang sama masih memungkinkan menimbulkan gangguan terhadap tanaman. Oleh sebab itu, untuk kategori tanaman yang belum berproduksi maka pemeliharaan sapi potong belum dapat dilakukan dengan sistem ekstensif/penggembalaan, tetapi mempunyai potensi sebagai lahan penghasil hijauan terutama leguminosa yang ditanam dan berfungsi sebagai penutup tanah (canopy). Untuk itu, sistem potong-angkut (cut and carry) untuk hijauan yang dihasilkan pada lokasi ini.

Luas lahan kebun sawit petani yang sudah berproduksi berkisar antara 0,5-12 Ha dan yang belum berproduksi berkisar antara 0-14 ha. Gambaran penguasaan luas lahan kebun sawit petani secara keseluruhan pada lokasi penelitian seperti terlihat pada Tabel 2.

Tabel 2. Luas Lahan Kebun Sawit Petani berdasarkan tingkatan produksi di Kenagarian Padang Laweh Kabupaten Dharmasraya

\begin{tabular}{cccccc}
\hline No. & Kondisi Kebun & $\begin{array}{c}\text { Minimum } \\
(\mathrm{Ha})\end{array}$ & $\begin{array}{c}\text { Maksimum } \\
(\mathrm{Ha})\end{array}$ & $\begin{array}{c}\text { Rata-rata } \\
(\mathrm{Ha})\end{array}$ & SD \\
\hline 1. & Belum berproduksi & 0 & 14 & 2,07 & 3,36 \\
2. Sedang berproduksi & 1,5 & 12 & 3,04 & 2,60 \\
$\quad \begin{array}{l}\text { Total } \\
\text { Total }\end{array}$ & & & 5,11 & \\
\hline
\end{tabular}

Luas lahan kelapa sawit yang dimiliki petani dipertimbangkan sebagai potensi ketersediaan pakan sapi. Keberadaan pakan merupakan faktor produksi utama yang dibutuhkan untuk memelihara sapi potong. Komponen pakan dalam produksi ternak berpengaruh langsung terhadap produktivitas ternak (laju pertumbuhan, tingkat morbiditas, dan mortalitas, tingkat reproduktivitas induk) (Suryanto et al., 2002), dan juga berpengaruh signifikan terhadap biaya produksi (De Boer dan Bickel, 1988). Dari segi teknis, kualitas dan kuantitas pakan haruslah memenuhi standar kebutuhan ternak untuk mencapai tingkat produktivitas yang diharapkan, sedangkan dari segi ekonomis biaya pakan merupakan komponen tertinggi yaitu sekitar 60-70\% dari total biaya produksi.

Pada perkebunan kelapa sawit terdapat potensi vegetasi rumput-rumput liar dan tanaman penggangu yang bisa dimakan oleh ternak seperti: Axonopus compresus, Ottochloa nodosa, Paspolum conjugotu, seperti terlihat pada Gambar 1. Produksi rumput liar yang dapat digunakan sebagai pakan ternak berkisar antara 3-5 ton/ha/tahun (Anomious, 1981 dalam Aritonang,1989). Selain rumput liar, pada lahan kelapa sawit juga dapat dilakukan budidaya penutup lahan berupa leguminosa terutama pada 2 (dua) tahun pertama penanaman kelapa sawit. Jenis spesies leguminosa yang sering digunakan sebagai tanaman penutup lahan adalah Callopogonium mucunoides, Centrocema pubescent, Pueraria javanica, Psophocarpus palustris, Callopogonnium caerulium, dan Muchuma cochinensisc (Direktorat Jendral Perkebunan,1984; Risza,1995).

Tujuan penanaman leguminosa penutup tanah pada lahan kelapa sawit adalah untuk mengurangi erosi pembukaan tanah, menambah bahan organik dan cadangan unsur hara, memperbaiki aerasi, menjaga kelembagaan tanah, menekan perkembangan gulma, menghemat penyiangan, dan pemupukan serta menekan gangguan kumbang oryctes (Risza, 1995). Tanaman budidaya penutup lahan merupakan faktor tindakan kultur teknis dalam budidaya kelapa sawit 
Tabel 3. Komposisi nutrient hijauan dan limbah sawit pada kebun sawit lokasi penelitian

\begin{tabular}{|c|c|c|c|c|c|c|c|c|c|c|}
\hline \multirow{2}{*}{ Bahan } & \multirow{2}{*}{$\begin{array}{l}\text { BK } \\
(\%)\end{array}$} & Abu & $\mathrm{BO}$ & PK & NDF & ADF & Hemi sellulosa & Sellulosa & Lignin & Silika \\
\hline & & \multicolumn{9}{|c|}{---------------------------------------- \% ------------------------------------- } \\
\hline Rumput & 18,80 & 8,66 & 80,29 & 11,06 & 66,35 & 36,29 & 30,06 & 26,66 & 8,87 & 1,16 \\
\hline Pelepah sawit tanpa kulit & 18,61 & 4,71 & 84,11 & 2,93 & 56,37 & 35,91 & 20,46 & 27,66 & 5,17 & 3,09 \\
\hline
\end{tabular}

Sumber : Analisis pada Laboratorium Gizi Ruminansia Faterna Unand, 2012.

yang mempengaruhi produktivitas kelapa sawit. Di areal perkebunan, intensitas cahaya matahari yang mencapai permukaan tanah sangat dipengaruhi oleh umur tanaman pokok. Penanaman beberapa macam legum dan tumbuhnya beberapa jenis rumput di areal perkebunan kelapa sawit juga mengalami fluktuasi produksi mengikuti perubahan tinggi-rendahnya intensitas cahaya matahari.

Dari tanaman leguminosa penutup lahan dapat dihasilkan produksi hijauan setara dengan 5-7 ton $\mathrm{BK} / \mathrm{ha} /$ tahun pada dua tahun pertama penanaman kelapa sawit, yang akan menurun menjadi 5-1 ton BK/ ha/tahun pada umur 2 hingga 5 tahun. Penurunan tersebut disebabkan oleh makin lebarnya canopy sehingga menyebabkan penurunan intensitas cahaya matahari. Tanaman penutup akan hilang dan akan digantikan oleh rumput berkualitas rendah dengan produksi 1 ton $\mathrm{BK} / \mathrm{ha}$ /tahun ketika pohon kelapa sawit mulai berumur 6 tahun (Umiyasih dan Anggraeni, 2003).

Limbah sawit berupa batang kelapa sawit juga berpotensi sebagai bahan pakan dasar untuk menggantikan hijauan sebagian atau seluruhnya. Penelitian Oshio et al. (1988) menunjukan bahwa batang kelapa sawit dapat digunakan dalam pakan sebanyak 30\% dari total pakan. dengan komposisi $30 \%$ batang sawit dan 70\% konsentrat diperoleh pertambahan berat badan 0,66-0,72 kg pada sapi. Sedangkan pelepah sawit dapat digunakan sebagai pengganti rumput, pelepah dapat diberikan dalam bentuk segar maupun silase.

Pelepah sawit yang memiliki daun juga dapat dikategorikan sebagai limbah perkebunan sawit yang harus dibuang dari batangnya mencapai 2024 pelepah/pohon/tahun. Pelepah dan daun bisa dimanfaatkan sebagai bahan pakan ternak sapi. Abu Hassan dan Ishida melaporkan bahwa pelepah kelapa sawit dapat dipergunakan sebagai bahan pakan ternak ruminansia, sebagai sumber pengganti hijauan atau dapat dalam bentuk silase yang dikombinasikan denagan bahan lain atau konsentrat sebagai bahan campuran. Studi awal yang dilakukan Abu Hassan dan Ishida (1992) menunjukkan bahwa tingkat kecernaan bahan kering pelepah dapat mencapai $45 \%$. Hal yang sama berlaku untuk daun kelapa sawit yang secara teknis dapat dipergunakan sebagai sumber atau pengganti pakan hijauan tetapi harus diberi perlakuan terlebih dahulu. Pemanfaatan pelepah sawit sebagai bahan pakan ternak juga harus mempertimbangkan aspek keseimbangan bahan organik di kebun, dimana biasanya pelepah sawit dikembalikan atau disebar ke kebun untuk menjaga tingkat kesuburan tanah serta mendukung usaha perkebunan kelapa sawit berkelanjutan.

Komposisi nutrien hijauan dan limbah pada kebun sawit rakyat pada lokasi penelitian seperti terlihat pada Tabel 3 .

Pelepah sawit dengan kulitnya mempunyai kandungan lignin cukup tinggi yaitu 17,4\%. Dengan kandungan lignin yang cukup tinggi, maka sebelum diberikan kepada ternak dilakukan perlakuan fisik, kimia ataupun biologi misalnya dengan menggunakan probiotik atau dikombinasikan dengan suplementasi, seperti dengan penggunaan $\mathrm{NaOH}$ yang bertujuan untuk meningkatkan kecernaan dengan memutuskan ikatan selulosa atau hemiseluosa dengan lignin, sehingga energi tersedia dapat meningkat, teknik ini telah dicobakan pada batang dan pelepah sawit (Oshio et al., 1988). Pemberian daun sawit disarankan jangan melebihi 20\% dari ransum, penggunaan daun sawit lebih dari $20 \%$ sebaiknya diberi pre-treatmen lebih dahulu karena daun sawit dibatasi oleh tinggi kadar lignin, sehingga perlu dilakukan pengolahan untuk meningkatkan daya cerna melalui perlakuan fisik, senyawa kimia, biologis, atau kombinasi. Batubara (2002), hasil penelitianya menunjukan bahwa penggunaan daun sawit segar sebagai pengganti hijauan dalam konsentrat menngandung 30\% BIS, memberikan pertambahan berat badan 760 g/ekor/ hari dengan $\mathrm{R} / \mathrm{C}$-ratio 1,5 pada sapi persilangan.

Dengan pemeliharaan sapi potong secara ekstensif ternak hanya dilepaskan di dalam kebun sawit dan ia mendapatkan pakannya dari hijauan yang tumbuh sebagai gulma di dalam kebun yang sudah berumur di atas dua tahun. Potensi lahan untuk menghasilkan hijauan akan lebih besar lagi bila dilakukan penanaman leguminosa sebagai penutup tanah pada tahun-tahun awal penanaman kelapa sawit (2 tahun pertama). Selain itu juga memanfaatkan limbah kebun sawit seperti pelepah dan daun yang setiap pemanenan buah dilakukan pemangkasan.

Bila jarak tanam kelapa sawit 9x9 m, maka setiap ha akan terdapat sebanyak 140 batang kelapa sawit. Jarak tanam akan tergantung kepada kondisi lahan misalnya kemiringan dan bentuk permukaan. Pada permukaan yang bergelombang atau perbukitan penanaman dilakukan lebih jarang, sehingga setiap ha lahan memiliki jumlah pohan yang lebih sedikit. Jumlah pohon dan ukuran (umur) pohon akan mempengaruhi jumlah biomass dari pelepah dan daun yang dapat dijadikan sumber pakan ternak sapi.

Pada lokasi penelitian, setiap ha memiliki \pm 130 
Tabel 4. Potensi rata-rata sumber pakan sapi potong pada kebun kelapa sawit per petani di Kenagarian Padang Lawas, Kabupaten Dharmas Raya

\begin{tabular}{|c|c|c|c|c|c|c|}
\hline \multirow{2}{*}{ Kondisi Kebun } & \multirow{2}{*}{$\begin{array}{l}\text { Luas rata-rata } \\
\qquad(\mathrm{Ha})\end{array}$} & \multicolumn{5}{|c|}{ Potensi pakan dalam ton BK/Thn } \\
\hline & & Leguminosa (canopy) & Rumput alam & Pelepah sawit & Daun sawit & Total \\
\hline Belum berproduksi & 2,07 & 8,28 & 0,00 & ,31 & 1,82 & 13,41 \\
\hline Sudah berproduksi & 3,04 & 0,00 & 3,04 & 6,30 & 5,40 & 14,74 \\
\hline Total & 5,11 & 8,28 & 3,04 & 9,61 & 7,22 & 28,15 \\
\hline
\end{tabular}

pohon kelapa sawit. Setiap pohon dapat menghasilkan 20-24 pelepah/tahun dengan berat rata-rata $2,2 \mathrm{~kg}$ setelah dikupas kulitnya dan daun $\pm 0,3 \mathrm{~kg} /$ pelepah. Dengan bahan kering pelepah dan daun masingmasing $18,61 \%$ dan $45,74 \%$, maka setiap ha kebun kelapa sawit pada lokasi penelitian memiliki potensi bahan pakan $\pm 1,6$ ton BK. Bila tidak memanfaatkan pelepah dan daun sebagai limbah kebun, setiap ha nya hanya berpotensi menghasilkan \pm 4 ton rumput liar atau setara dengan \pm 1 ton BK hijauan. Rumput liar sudah dimanfaatkan untuk pakan sapi potong pada lokasi penelitian. Leguminosa sebagai canopy lahan pada saat pohon sawit berumur sampai dengan 2 tahun belum dilakukan dan limbah kebun sawit berupa pelepah dan daun sawit sejauh ini belum dimanfaatkan.

Bila pelepah, daun dan penanaman leguminosa penutup tanah dilakukan maka berarti setiap Ha kebun sawit petani, memiliki potensi pakan jauh lebih besar. Diskripsi potensi pakan sapi potong yang dimiliki oleh petani saat penelitian dilakukan seperti terlihat pada Tabel 4.

Bila kebutuhan pakan ternak sebanyak 3\% BK dari berat badan, maka setiap 1 ST (setara dengan berat $250 \mathrm{~kg}$ ) akan membutuhkankan $\pm 7,5 \mathrm{~kg} \mathrm{BK} /$ hari atau $\pm 2,7$ ton BK/ST/Thn. Dengan demikian potensi pakan yang tersedia pada kebun kelapa sawit rakyat pada lokasi penelitian mempunyai kapasitas tampung rata-rata sebanyak $\pm 10,4$ ST. Pada lokasi penelitian, pemilikan sapi potong yang dipelihara secara ekstensif pada kebun sawit berkisar antara 0,5-22,0 ST dengan rata-rata 4,35 ST. Dengan rata-rata pemeliharaan sapi potong saat ini (jumlah ternak riil) per petani ekuivalen dengan 4,35 ST, maka pemanfaatan pakan oleh petani baru mencapai 41,8 persen dari potensi pakan yang tersedia. Untuk mencapai kondisi optimal maka secara rata-rata tiap petani masih mempunyai potensi untuk menambah jumlah sapi potong sebanyak 6,05 ST lagi.

\section{Potensi Lahan dan Daya Dukung Pakan pada Wilayah Tanaman Pangan dan Hortikultura}

Data Departemen Pertanian (2010) memperlihatkan bahwa di Sumatera Barat terdapat 229.693 ha lahan sawah, yang terdiri dari 184.316 ha sawah beririgasi dan 45.337 ha sawah non-irigasi. Setiap ha sawah irigasi, mampu menghasilkan 8,29 ton jerami segar/tahun. Sedangkan pada lahan non-irigasi akan menghasilkan 7,97 ton/ha. Luas penguasaan dan pemilikan serta pemanfaatan lahan sawah baik yang beririgasi maupun yang non-irigasi bervariasi antar wilayah dan antar petani. Pada lokasi penelitian didapatkan, tidak semua responden memiliki lahan sawah walaupun ia tinggal diwilayah basis tanaman pangan. Luas penguasaan lahan sawah beririgasi petani yang menjadi responden berkisar antara 0,25-2 ha, dengan rata-rata 0,56 ha $\pm 0,61$.

Data keragaan penguasaan lahan sawah ini memberikan beberapa pemahaman terhadap kondisi sumberdaya petani, dan berimplikasi terhadap kesejahteraannya. Pertama, petani pada wilayah tanaman pangan bukan berarti semuanya mendapatkan penghasilan utamanya dari tanaman pangan khususnya padi. Hal ini terlihat dari adanya petani yang tidak menguasai lahan sawah apalagi memilikinya. Kelompok petani yang demikian cenderung hanya merupakan buruh tani, dan kalaupun melakukan penanaman padi hanya dilakukan pada lahan garapan yang sifatnya tidak tetap dan sangat rentan dalam penguasaan penggarapan. Kedua, angka standar deviasi yang rebih besar dari angka rata-rata dalam penguasaan lahan sawah memberikan informasi bahwa luas pemilikan sawah di wilayah tanaman mempunyai ketimpangan yang cukup tinggi diantara petani. Berbagai implikasi bisa terjadi karena penguasaan lahan yang timpang tersebut yang berakibat kepada tingkat efisiensi penggunaan sumberdaya lain yang dimiliki petani, misalnya tenaga kerja keluarga.

Dalam kondisi petani tanaman pangan yang demikian, maka pola integrasi berbagai komoditi pertanian khususnya CLS menjadi pilihan yang rasional untuk mewujudkan kesejahteraan petani yang lebih baik. Pada pola CLS, lahan sawah memberikan input produksi untuk ternak berupa pakan yang berasal hijauan dan jerami padi yang merupakan limbah pertanian dan menerima input untuk proses produksi padi berupa pupuk organik. Luas lahan akan menjadi faktor penentu terhadap jumlah hijauan dan jerami yang dapat dihasilkan dan selanjutnya ketersediaan pakan menentukan kapasitas tampung ternak yang dapat dipelihara pada setiap keluarga petani, terutama pemeliharaan ternak secara intensif.

Penelitian Kariyasa (2003) mendapatkan bahwa pada model integrasi tanaman ternak, petani mengatasi permasalahan ketersediaan pakan dengan memanfaatkan limbah tanaman yang mampu menyediakan pakan sekitar 33,3 persen dari total rumput. Selain meningkatkan "ketahanan pakan", integrasi tanaman dan ternak juga mampu menghemat tenaga kerja dalam kegiatan mencari rumput, sehingga memberi peluang bagi petani untuk meningkatkan jumlah skala pemeliharaan ternak.

Pada lokasi penelitian didapatkan bahwa jerami padi belum dimanfaatkan petani sebagai pakan ternak secara konsisten. Sejumlah kecil petani memanfaatkan bila warnanya masih relatif hijau sebagai tambahan 
rumput alam yang diberikan kepada ternak sapi. Pada umumnya jerami masih tetap sebagai limbah dan dibakar yang dipertimbangkan oleh petani sebagai pupuk untuk musim tanam berikutnya. Potensi pakan ternak sapi yang dapat digunakan pada wilayah tanaman pangan adalah berupa rumput kultur yang dibudidayakan di pinggiran lahan dan limbah padi berupa jerami dan limbah tanaman pangan lainnya seperti jagung dan kacang-kacang.

Wilayah pertanian hortikultura sebetul tidak jauh berbeda dengan wilayah tanaman pangan. Komoditi hortikultura khususnya sayur-sayuran diusahakan oleh petani karena didukung oleh kondisi alam terutama curah hujan, temperatur dan kelembapan. Sebagian besar petani menanam sayur-sayuran berupa kacangkacangan, terong, cabe adalah pada wilayah lahan persawahan yang dilakukan tumpang sari atau pola bergilir. Sedangkan jenis sayuran berdaun lebar seperti lobak, dan bawang dilakukan penananam pada daerah dataran tinggi. Pada daerah ini merupakan lahan kering yang hanya digunakan untuk menanam sayur-sayuran. Sama halnya dengan wilayah tanaman pangan, penguasaan lahan petani relatif kecil yang berkisar antara $0,2-1,0$ ha dengan rata 0,8 ha $\pm 0,3$ ha.

Pada lokasi penelitian, penanaman sayuran dilakukan dengan pola konvensial menggunakan input luar berupa pupuk, pestisida dan insektisida guna untuk meningkatkan jumlah produksi sayuran. Penggunaan input anorganik tersebut menyebabkan petani sulit untuk melakukan penanaman rumput unggul pada pematang/batas lahan. Selain itu, limbah komoditi sayuran tidak dimanfaatkan petani untuk pakan sapi karena karena kekuatirannya terhadap residu pestisida yang digunakannya untuk tanaman. Dengan demikian pada wilayah pertanian hortikultura ini potensi pakan ternak sapi lebih rendah dibandingkan dengan wilayah pertanian tanaman pangan.

\section{Potensi Tenaga Keja}

Dalam sistem usaha tani, tenaga kerja merupakan salah satu faktor produksi utama setelah adanya lahan. Menurut Simanjuntak (1998), tenaga kerja merupakan faktor produksi yang unik, yang berbeda dengan faktor produksi lain karena sumberdaya tenaga kerja tidak dapat dipisahkan secara fisik dari tenaga kerja itu sendiri. Pada pertanian rakyat, curahan tenaga kerja merupakan faktor penting yang diperhatikan selain kualitas tenaga kerja. Biasanya pertanian skala kecil akan menggunakan tenaga kerja dalam keluarga dan tidak memerlukan tenaga kerja ahli. Pemanfaatan tenaga kerja keluarga merupakan permasalahan mendasar yang akan menentukan keberlangsungan usaha petani dan berimplikasi terhadap keberlangsungan pembangunan secara nasional.

Tenaga kerja keluarga terdiri dari Bapak, ibu dan anak-anak, dimana anak-anak yang berumur diatas 15 tahun dihitung potensinya sebagai tenaga kerja dewasa, sedangkan anak yang berumur dibawah 15 tahun dihitung potensinya sebagai tenaga kerja anak- anak. Tenaga kerja pria dewasa yang bekerja 8 jam per hari dihitung 1 HKP ( Hari Kerja Setara Pria), wanita dewasa dihitung setara dengan 0,8 HKP dan tenaga kerja dibawah 15 tahun dihitung 0,5 HKP untuk pria dan 0,4 HKP untuk wanita. Curahan tenaga kerja keluarga petani dilakukan untuk kegiatan produktif (menghasilkan pendapatan) dan kegiatan reproduktif (tidak menghasilkan pendapatan langsung). Tenaga kerja wanita biasanya lebih banyak curahannya untuk kegiatan reproduktif seperti kegiatan domestik (mengasuh anak, memasak, mencuci, membersihkan rumah, dll.). Sedangkan tenaga kerja pria mayoritas curahannya untuk kegiatan produktif baik on farm maupun off-farm. Hasil penelitian pada wilayah penelitian seperti terlihat pada Tabel 5 .

Tabel 5. Rata-rata tenaga kerja tersedia, curahan dan potensi pada kelurga petani di wilayah penelitian

\begin{tabular}{lccc}
\hline Wilayah Penelitian & $\begin{array}{c}\text { Rata-rata Tenaga } \\
\text { Kerja Tersedia } \\
\text { (HKP) }\end{array}$ & $\begin{array}{c}\text { Rata-rata Curahan } \\
\text { TK Utk Pekerjaan } \\
\text { Utama + Kegiatan } \\
\text { Reproduktif }\end{array}$ & $\begin{array}{c}\text { Potensi Tenaga } \\
\text { Kerja Rata-rata } \\
\text { (HKP) }\end{array}$ \\
\hline Perkebunan & $1,95 \pm 0,53$ & $1,4 \pm 0,52$ & $0,55 \pm 0,48$ \\
Tanaman Pangan & $2,14 \pm 0,74$ & $1,4 \pm 0,48$ & $0,74 \pm 0,68$ \\
Hortikultura & $2,12 \pm 0,86$ & $1,2 \pm 0,65$ & $0,98 \pm 0,76$ \\
\hline
\end{tabular}

Sebagaimana terlihat pada Tabel 5 , bahwa lebih kurang 70\% dari tenaga kerja keluarga yang dimiliki oleh petani sudah digunakan untuk pekerjaan utama (kegiatan produktif) dan pekerjaan-pekerjaan yang merupakan kegiatan reproduktif. Tenaga kerja keluarga yang dikategorikan potensi untuk dapat digunakan untuk kegiatan produktif yang bukan pekerjaan utama tinggal rata-rata $0,55 \pm 0,48 \mathrm{HKP}$ pada wilayah perkebunan, $0,74 \pm 0,68 \mathrm{HKP}$ pada wilayah tanaman pangan, dan yang paling banyak rata-rata wilayah pertanian hortikultura yaitu rata-rata $0,98 \pm 0,76 \mathrm{HKP}$.

Potensi tenaga kerja yang dapat digunakan untuk kegiatan pemeliharaan ternak yang statusnya bukan pekerjaan utama pada setiap keluarga adalah sisa tenaga kerja yang sudah dicurahkan untuk pekerjaan utama. Kecilnya ketersediaan tenaga kerja pada keluarga dapat menjadi faktor pembatas untuk meningkatkan jumlah ternak yang dipelihara bila pemeliharaan dilakukan secara intensif pada peternakan rakyat. Kondisi demikian terlihat dari perbandingan jumlah sapi yang dipelihara oleh petani peternak, dimana pada wilayah perkebunan yang memelihara sapi dengan sistem ekstensif melepaskan di kebun sawit, rata-rata pemilikan lebih banyak. Sedangkan pada wilayah pertanian tanaman pangan dan hortikultura yang pemeliharaan dilakukan dengan sistem intensif jumlah rata-rata pemeliharaan sapinya jauh lebih sedikit.

\section{SIMPULAN}

Adapun simpulan dari hasil penelitian ini dapat dikemukakan sebagai berikut:

(1) Pemeliharaan sapi potong dilakukan bukan menjadi komoditi utama dalam sistem 
pertanian, namun mempunyai arti penting bagi petani terutama sebagai tabungan yang sewaktu-waktu dapat dijual bila membutuhkan uang yang jumlahnya cukup besar untuk ukuran keluarga petani. Jumlah sapi yang dipelihara pada wilayah pertanian berbasis perkebunan lebih banyak dibandingkan dengan wilayah tanaman pangan dan hortikultura. Sistem pemeliharaan yang dilakukan pada wilayah perkebunan secara ekstensif dan pada wilayah tanaman pangan dan hortikultura dipelihara dengan sisten semi intensif sampai intensif. Namun demikian, pada ketiga wilayah penelitian belum menerapkan sistem usaha tani terintegrasi antara tanaman dengan sapi potong sebagai mana konsepnya.

(2) Sumberdaya petani berupa lahan dan sumber pakan pada ketiga wilayah penelitian didapatkan dalam jumlah dan daya dukung yang berbeda. Potensi pada wilayah perkebunan lebih besar dibandingkan dengan wilayah tanaman pangan dan perkebunan. Tetapi potensi tenaga kerja keluarga pada wilayah tanaman pangan dan hortikultura hampir sama pada ketiga wilayah. Potensi tenaga kerja keluarga yang masih memungkinkan untuk dimanfaatkan memelihara sapi potong kurang dari $1 \mathrm{HKP} /$ hari.

(3) Inovasi dan teknologi tepat guna untuk memanfaatkan potensi sumberdaya yang ada khususnya potensi pakan ternak belum dimanfaatkan. Keengganan petani disebabkan oleh kecilnya skala usaha dan usaha hanya merupakan sambilan. Oleh sebab itu, aplikasi inovasi dan teknologi tepat guna dipandang petani sebagai yang kurang efisien bila dilakukan secara individu petani.

Kedepan, penguatan kelembagaan petani sebagai wadah aplikasi inovasi dan teknologi perlu dilakukan. Dengan adanya lembaga petani, inovasi dan teknologi dapat diaplikasikan secara kolektif sehingga meningkatkan efisiensi usaha petani secara keseluruhan.

\section{DAFTAR PUSTAKA}

Agustar, A., Andri, dan Fitrini. 2004. Analisis Potensi Wilayah Untuk Pengembangan Sapi Potong di Sumatera Barat. Laporan Penelitian. Biaya SP4 Dirjen Dikti.

Agustar, A. dan Jaswandi. 2006. Melirik Potensi Sapi Lokal Dalam Upaya Mewujudkan Kecukupan Daging dan Pengembangan Kawasan Pembangunan Peternakan. Seminar Nasional Revitalisasi Ternak Lokal di Padang 11 September 2006.

Agustar, A. 2008. Analisa Upaya Pengembangan Ternak Besar Terhadap Swasembada Daging Nasional. Laporan Penelitian Kerjasama dengan Pemda Kabupaten Kuantan Singingi.

Agustar, A. 2010. Potensi Usaha Sapi Potong Dalam Pengentasan Kemiskinan Di Wilayah Pedesaan Propinsi Sumatera Barat. Makalah Round Table Discussion Program Satu Sapi Satu Petani. Fakultas Peternakan-Unand Padang.

Batubara, L. 2002. Potensi biologis daun kelapa sawit sebagai pakan basal dalam ransum sapi potong. Prosiding Seminar Nasionnal Teknologi Peternakan dan Veteriner. Puslitbang Peternakan Badan Litbang Pertanian. Departemen Pertanian. Bogor.

Chen, C.P. and Dahlan, I. 1995. In Proc. 1st Int.Symp. on Integration of livestock to Oil Palm Prod. FAO, Rome.pp. 35-49

Davendra. 1993. Sustainable Animal Production from Small Farm System in South-Easth Asia. FAO Animal Production and Health Paper. 106. FAO, Roma.

Direktorat Pangan dan Pertanian-Bappenas. 2010. Stratgi Kebijakan Dalam Pencapaian Swasembada Daging Sapi 2014. Naskah Kebijakan. Bappenas.

Ilham, N., B. Wiryono, I.K. Kariyasa, M.N.A., dan Hastuti. 2001. Analisis Penawaran dan Permintaan Komoditi Peternakan Unggulan. Laporan Hasil Penelitian. Pusat Penelitian Sosial Ekonomi Pertanian. Badan Litbang Pertanian. Departemen Pertanian. Bogor.

Kariyasa, K. 2003. Hasil laporan Pra Survei Kelembagaan Usaha Tanaman-Ternak Terpadu dalam Sistem dan Usaha Agribisnis. Proyek PAATP. Jakarta.

Lab. Reproduksi Ternak Fak. Peternakan. 2006. Penampilan Reproduksi Sapi Pesisir. Laporan Penelitian. Fakultas Peternakan. Unand. Padang.

Mosher, AT. 1966. Getting Agricultural Moving. Terjemahan: S. Krisnandhi dan B.Samad. Cetakan ke-8 1983. Penerbit Yasaguna. Jakarta.

Risza, R.1995. Budidaya Kelapa Sawit. A.A.K.Kanisius. Yogyakarta.

Umiyasih, U. dan Yeny Nur Anggraeni. 2003. Keterpaduan Sistem Usaha Perkebunan Dengan Ternak: Tinjauan Tentang Ketersediaan Hijauan Pakan Untuk Sapi Potong di Kawasan Perkebunan Kelapa Sawit. Prosiding Lokakarya Sistem Integrasi Kelapa Sawit-Sapi. Hal. 156-166. 